\title{
ANALISIS YURIDIS MEKANISME PENYELESAIAN SENGKETA PERDAGANGAN INTERNASIONAL (DALAM KERANGKA GATT-WTO)*
}

\author{
Ukas \\ Fakultas Ilmu Sosial dan Humaniora, Universitas Putera Batam, \\ Jalan R. Soeprapto, Tembesi Batam \\ e-mail: ukasibrahim@gmail.com
}

\begin{abstract}
The dispute settlement mechanism of the World Trade Organization and the General Agreement on Tariffs and Trade, is a document containing juridical elements, stated about the rights and obligations of the participating countries of the agreement explicitly, of course, often lead to disputes. GATT as an institution has implemented procedures and procedures to deal with disputes arising between participating countries, in the context of international law in general. The process in which the party to the dispute is encouraged to counsel and endeavor to settle the dispute among themselves, and or through the WTO. The formulation of the problem in this research is how the dispute settlement mechanism in international trade and the impact of what is caused in the international trade sector. The method used in this research is empirical juridical analysis, from existing data, with qualitative analysis approach. The point is that the settlement of disputes refers to the provisions and Articles contained in GATT 1947 with the stages of consultation and or the establishment of a panel. The impact associated with international trade is to facilitate importexport and create harmony in international trade between countries.
\end{abstract}

Keywords: Mechanism, Impact, Dispute Resolution, International Trade

\begin{abstract}
Abstrak
Mekanisme penyelesaian sengketa World Trade Organization dan General Agreement on Tariffs and Trade, adalah suatu dokumen yang mengandung unsur yuridis, tercantum tentang hak dan kewajiban negara peserta perjanjian secara eksplisit, tentunya sering menimbulkan sengketa. GATT sebagai suatu lembaga telah menerapkan tatacara dan prosedur untuk menangani sengketa yang timbul antara negara peserta, dalam kontek hukum internasional secara umum. Proses di mana pihak yang bersengketa dianjurkan supaya berembuk dan berusaha untuk menyelesaikan sengketa diantara mereka sendiri, dan atau melalui WTO. Rumusan masalah dalam penelitian ini adalah Bagaimana mekanisme penyelesaian sengketa dalam perdagangan internasional dan dampak apa saja yang ditimbulkan dari ketentuan tersebut di bidang perdagangan internasional. Metode yang dipergunakan dalam penelitian ini adalah kajian analisis secara yuridis empiris, dari data yang ada, dengan pendekatan analisis secara kualitatif. Simpulannya adalah penyelesaian sengketanya mengacu pada ketentuan dan Pasal-Pasal yang ada dalam GATT 1947 dengan tahapan konsultasi dan atau pembentukan suatu panel. Dampaknya terkait dengan perdagangan internasional adalah memperlancar ekspor-impor dan menciptakan keharmonisan dalam perdagangan internasional antar negara.
\end{abstract}

Kata Kunci: Mekanisme, Dampak, Penyelesaian Sengketa, Perdagangan Internasional

\footnotetext{
* Naskah diterima: 19 Agustus 2018, direvisi: 16 September 2018, disetujui untuk terbit: 23 September 2018
} 


\section{PENDAHULUAN}

Perdagangan

internasional

memfokuskan dalam pengembangan dari pasar terbuka. Diketahui bahwa bermacam kebudayaan yang makmur sepanjang sejarah yang bertransaksi dalam perdagangan. Berdasarkan hal ini, secara teoritis rasionalisasi sebagai kebijakan dari perdagangan bebas akan menjadi menguntungkan ke negara berkembang sepanjang waktu. Teori ini berkembang dalam rasa modernnya dari kebudayaan komersial di Inggris, dan lebih luas lagi ke Eropa, sepanjang lima abad yang lalu. Sebelum kemunculan perdagangan bebas, dan keberlanjutan hal tersebut sampai pada saat ini. Kebijakan dari merkantilisme telah berkembang di Eropa di tahun 1.500. Ekonomi awal yang menolak merkantilisme. (David Ricardo dan Adam Smith, 2002: 155).

Perubahan dalam hukum perdagangan internasional sebagaimana diketahui memunculkan negara-negara sosialis yang diawali dengan revolusi sosial telah menimbulkan pergeseran prinsip hukum internasional. Hal ini di kerenakan munculnya kekuatan yang mengimbangi negara-negara liberal.

Pesatnya pertumbuhan ekonomi di negara-negara, termasuk Indonesia, membuat pusing negara-negara maju, seperti USA, Uni Eropa, dan lain-lain. Sektor perdagangan menjadi sangat penting peranannya dalam pembinaan perekonomian, baik dalam perdagangan domestik maupun perdagangan internasional yang menuju perdagangan bebas yang semakin kompetitif.
Sebagaimana diketahui bahwa di seluruh dunia berbagai negara melakukan tindakan-tindakan deregulasi secara silih berganti. Peraturan Perundang-undangan tersebut dalam proses perkembangannya semakin terasa pengaruhnya atas pelaksanaan tindakan-tindakan pengusaha dalam perdagangan internasional tersebut. Dalam kekaitan tersebut kegiatan para pelaku perdagangan internasional di suatu saat dapat menimbulkan terjadinya perselisihan yang melahirkan sengketa perdagangan internasional, seperti sengketa antara Indonesia dengan Amerika Serikat dalam kasus rokok keretek. Kasusus lainnya adalah antara Amerika Serikat dengan China dalam kasus penjualan kendaraan.

Menurut Syahmin AK, pada tahun 2004 "Bahwa maraknya penyelesaian sengketa, Dispute Settlement Body (DSB) Organisasi Perdagangan Dunia (WTO), ini berarti bahwa USA telah mengikuti jejak Jepang dan Uni Eropa dalam memberikan indikasi bahwa mereka tidak puas dengan hasil negosiasi bilateral dengan Indonesia dan meminta WTO mengambil keputusan sesuai dengan peraturan yang berlaku. Tiga kekuatan ekonomi yang mendominasi dunia menggugat Indonesia. Hal ini jelas merupakan suatu hal yang sangat serius.

Suatu sengketa dapat terjadi apabila ada pertentangan, misalnya karena adanya pelanggaran ketentuan GATT yang menimbulkan kerugian salah satu pihak. Di dalam GATT tidak mengenal istilah ganti rugi atau penyitaan karena GATT mengatur tingkah laku perdagangan untuk 
Ukas: Analisis Yuridis Mekanisme Penyelesaian Sengketa Perdagangan Internasional...

mencapai harmonisasi antara peraturan internasional dengan kebijaksanaan nasional. Untuk menentukan sumber sengketa, GATT mensyaratkan adanya multification atau impairment, sebagaimana diatur dalam article XXIII yang mengatur antara lain terjadinya kesalah pahaman, dan menimbulkan kerugian diderita oleh suatu negara.

Kebijakan perdagangan yang merupakan bagian integral dari pembangunan nasional dilakukan dengan memperhatikan gejala dan perkembangan yang terjadi di negara lain yang berpengaruh pada perekonomian nasional, keberhasilan perdagangan luar negeri semakin menentukan proses pembangunan nasional. Hal ini menyadarkan bahwa mau tidak mau, suka tidak suka, kita tidak bisa melepaskan diri dari globalisasi atau pasar bebas yang didukung dari hasil Putaran Uruquay Round contohnya Indonesia dengan meratifikasi hasil Putaran Uruquay di Marakesh Marocco dengan UndangUndang Nomor 7 Tahun 1994. Dibentuknya World Trade Organization sebagai lembaga penerus General Agreement on Tariff and Trade juga turut disesuaikan dengan ketentuan dalam perjanjian.

Untuk mencapai tujuan perdagangan internasional dan tercapainya fungsi WTO perlunya diadakan suatu regulasi dan atau pengaturan yang saling menguntungkan yang diarahkan pada pengaturan tarif secara substansial dan juga hambatan-hambatan non tarif perdagangan internasional (Syahmin AK,
2004: 51). Untuk menghilangkan perlakuan diskriminatif dalam hubungan perdagangan internasional. lebih lanjut Syahmin AK memaparkan WTO sebagai organisasi perdagangan. WTO merupakan suatu lembaga perdagangan multilateral yang parmanen. Sebagai suatu organisasi permanen WTO akan lebih kuat dari pada GATT selama ini. (Syahmin AK, 2004: 244) . Hal tersebut di atas sejalan tentang tujuan dan fungsi GATT yang dikemukakan oleh Huala Adolft dan dan A. Chandrawulan tentang tujuan dan fungsi GATT antara lain yakni "meningkatkan taraf hidup umat manusia, meningkatkan kesempatan kerja serta meningkatkan pemanfaatan kekayaan alam dunia".

WTO dilengkapi dengan sejumlah organisasi antara lain adalah ministerial conference, council for trade related aspects of international property rights dan dispute setlement body (Badan Penyelesaian Sengketa).

Pesatnya pertumbuhan perekonomian negara-negara (ASEAN), termasuk Indonesia, kurung waktu terakhir ini mau tidak mau telah membuat pusing negaranegara sedang berkembang, negara maju seperti USA, Uni Eropa dan negaranegara di sekitar ASEAN lainnya (Syahmin AK, 2004: 66). Keberadaan perdagangan internasional sangat penting, keberadaan dan peranannya dalam pembinaan perekonomian baik dalam perdagangan regional-domestik maupun perdagangan internasional yang menuju perdagangan bebas yang semakin kompetitif. Berdasarkan pendahuluan dari 
latar belakang penulisan ini penulis merumuskan permasalahannya sebagai berikut: Bagaimana mekanisme penyelesaian sengketa perdagangan internasional dalam kerangka GATTWTO dan Dampak apa saja dari ketentuan penyelesaian sengketa perdagangan internasional melalui WTO.

\section{METODE PENELITIAN}

Jenis penelitian ini bersifat normatif empris, menggunakan data sekunder yang relevan dengan pembahasan, dan data yang ada dianalisis secara kualitatif. Tujuan dari penelitian ini adalah:

1. Mengetahui dan memahami secara prespektif tentang mekanisme penyelesaian sengketa dalam perdagangan internasional.

2. Mengetahui dan memahami dampak dari adanya ketentuan penyelesaian sengketa dalam perdagangan internasional.

Kegunaannya secara teori diharapkan sebagai sumbangsih dalam pengembangan hukum perdagangan internasional khususnya masalah sengketa perdagangan internasional dalam kerangka GATT-WTO, dan secara praktek diharapkan sebagai pengetahuan jika dirasa perlu pada para pihak yang bergerak pada kegiatan sengketa dalam perdagangan internasional.

\section{PEMBAHASAN}

\section{Aspek Hukum dan Mekanisme Dalam Penyelesaian Sengketa Perdagangan Internasional Dalam Kerangka GATT-WTO}

$\begin{array}{rlr}\text { Sengketa } & \text { Dalam } & \text { Perdagangan } \\ \text { Internasional. } & \text { Misalnya } & \text { transaksi- }\end{array}$ transaksi atau hubungan dagang banyak bentuknya, dan berupa hubungan jual-beli barang, pengiriman dan penerimaan barang, produksi barang dan jasa berdasarkan suatu kontrak, dan lain-lain. Semua transaksi tersebut sarat dengan potensi melahirkan sengketa. Umumnya sengketa-sengketa dagang kerap di dahului oleh penyelesaian melalui proses negosiasi. Jika cara penyelesaian ini gagal atau tidak berhasil, barulah ditempuh cara-cara lainnya seperti penyelesaian melalui pengadilan atau arbitrse. Penyerahan sengketa, baik kepada pengadilan maupun kepada arbitrase, kerap kali didasarkan pada suatu perjanjian diantara para pihak. Langkah yang biasa ditempuh adalah dengan membuat suatu perjanjian atau memasukkan suatu klausul penyelesaian sengketa ke dalam kontrak atau perjanjian yang mereka buat, baik ke pengadilan maupun ke badan arbitrase. Artinya bahwa tidak semua sengketa itu harus melalui GATT.

Dasar hukum bagi forum atau badan penyelesaian sengketa yang akan menangani sengketa adalah kesepakatan para pihak. Kesepakatan tersebut diletakkan, baik pada waktu kontrak ditandatangani atau setelah sengketa itu muncul. Biasanya kelalaian para pihak 
Ukas: Analisis Yuridis Mekanisme Penyelesaian Sengketa Perdagangan Internasional...

untuk menentukan forum ini akan berakibat pada kesulitan dalam penyelesaian sengketanya karena dengan adanya kekosongan pilihan forum tersebut akan menjadi alas an yang kuat bagi setiap forum untuk menyatakan dirinya berwenang untuk memeriksa suatu sengketa. Lazimnya dalam sistem hukum (Common Law) dikenal dengan konsep "Long Form Jurisdiction". Dengan konsep ini, pengadilan dapat menyatakan kewenangannya untuk menerima setiap sengketa yang dibawa ke hadapannya meskipun hubungan antara pengadilan dengan sengketa tersebut tipis sekali. Misalnya badan peradilan di Amerika Srikat dan Inggris kerap kali selalu menerima sengketa yang para pihak serahkan ke hadapannya meskipun hubungan atau keterkaitan sengketa dengan badan peradilan sangat kecil.

Di samping forum pengadilan atau badan arbitrase, para pihak dapat pula menyerahkan sengketanya kepada cara penyelesaian sengketa, yang lazim dikenal sebagai ADR (Alternative Dispute Resolution) atau APS (Alternatif Penyelesaian Sengketa). Pengaturan alternatif di sini dapat berupa cara alternative di samping pengadilan. Bisa juga berarti alternatif penyelesaian sengketa secara umum, yaitu berbagai alternatif penyelesaian melalui pengadilan. Apabila timbul sengketa, maka GATT mempersiapkan suatu mekanisme dengan prosedur tersendiri untuk menangani sengketa tersebut. Mekaisme ini telah mengalami evlusi sejak tahun 1947. Dengan adanya paket hasil perundingan Uruquay Round yang juga membentuk lembaga baru, World Trade Organization (WTO) sebagai pengganti dan penerus GATT, maka sistem penyelesaian isi guna menyusun sengketa yang telah dikembangkan oleh GATT juga semakin disempurnakan lagi.

Sebagai langkah menangani masalah perdagangan internasional pada bulan Februari 1946, (ECOSOC) suatu badan di bawah PBB, pada sidang pertamanya telah mengambil resolusi untuk mengadakan konferensi guna menyusun piagam internasional di bidang perdagangan. Pada waktu yang bersamaan, pemerintah Amerika Serikat (AS) mengeluarkan suatu draft mengenai Sembilan piagam untuk International Trade Organization (ITO).

Prinsip-prinsip penyelesaian sengketa secara damai (Huala Adolf, 2004: 18) dari berbagai aturan hukum intrrnasional, terdapat beberapa prinsip-prinsip mengenai penyelesaian sengketa internasional, yaitu:

- $\quad$ Prinsip itikad baik (Good Faith)

- Prinsip larangan penggunaan kekerasan dalam penyelesaian sengketa

- Prinsip kebebasan memipeace, dengan cara-cara penyelesaian sengketa

- Prinsip kebersamaan memilih hukum yang akan diterapkan terhadap pokok sengketa

- Prinsip kesepakatan para pihak yang bersengketa (berkonsensus)

- Prinsip exhaustion of local remedies 
- Prinsip-prinsip hukum internasional tentang kedaulatan, kemerdekaan dan integritas wilayah Negara.

Cara-cara penyelesaian sengketa internasional secara damai meliputi negosiasi, pencarian fakta, jasa-jasa bank, mediasi, konsiliasi, arbitrase, dan pengadilan internasional. Tujuan dibentuknya PBB, yaitu menjaga kedamaian internasional tercantum di dalam Pasal 1 Piagam, yang berbunyi: "To maintain international peace and security, and to that and: to take effective collective measures for the prevention and removal of threats to the peace, and for the suppression of acts of angression or other breaches of the peace, and to bring about by peaceful means, and in conformity with the principles of justice and international law, adjustment or settlement of international disputes or situations which might lead to a breach of the peace." Kedamaian dan keamanan internasional hanya dapat diwujudkan apabila tidak ada kekerasan yang digunakan dalam menyelesaikan sengketa, yang ditegaskan dalam Pasal 2 ayat (4) Piagam. Penyelesaian sengketa secara damai ini, kemudian dijelaskan lebih lanjut dalam Pasal 33 Piagam yang mencantumkan beberapa cara damai dalam menyelesaikan sengketa, diantaranya antara lain adalah negosiasi, enguiry arbutrase, judicial settlement atau pengadilan, dan organisasi-organisiaisi atau badan-badan regional.

GATT sebagai Sistem dalam perdagangan internasional. Persetujuan Umum Mengenai Tarif dan Perdagangan
(General Agreement on Tarif and Tariff Trade) yang biasa disingkat dengan GATT merupakan suatu perjanjian perdagangan multilateral yang disepakati pada tahun 1948, dimana tujuan pokoknya ialah untuk menciptakan pertumbuhan ekonomi dan pembangunan guna mencapai kesejahteraan umat manusia. Lebih lanjut GATT bertujuan untuk menjaga upaya agar perdagangan dunia dapat menjadi semakin terbuka supaya arus perdagangan dapat berkembang dengan mengurangi hambatan-hambatan dalam bentuk tarif maupun nontarif. GATT sebagai international mempunyai beberapa wajah, tergantung dari sisi mana penglihatan yang digunakan. Beberapa wajah GATT secara ringkas dapat digambarkan sebagai suatu sistem yang saling berkaitan yang mempunyai beberapa komponen. Perpaduan komponen tersebut secara efektif selama empat puluh tahun lebih. Komponen utama GATT sebagai lembaga internasional terdiri dari antara lain sebagai berikut (Syahmin AK, 2004: 78)

- GATT sebagai perjanjian internasional. Ini merupakan instrument formal yang memberikan baik batasan maupun gerak GATT sebagai lembaga. Perjanjian tersebut menentukan cakupan substansi yang termasuk dalam aturan permainan yang berlaku untuk semua negara peserta. Perjanjian ini merupakan dokumen legal.

- GATT sebagai forum Pengambilan Keputusan. Secara bersama dan melakukan consensus. Negara anggota 
Ukas: Analisis Yuridis Mekanisme Penyelesaian Sengketa Perdagangan Internasional...

GATT mengambil keputusan untuk menentukan kebijaksanaan bersama. Forum pengambilan keputusan ini juga merupakan forum negosiasi sejauh negara-negara yang berkepentingan memerlukan penyelesaian.

- GATT sebagai Forum Penyelesaian Sengketa. Dengan adanya suatu perjanjian formal, yang isinya mengikat, GATT juga menyediakan forum penyelesaian sengketa yang semakin berkembang dan semakin disempurnakan, terutama setelah selesainya Perundingan Uruguay. Salah satu kegiatan utama GATT adalah sebagai penyelesaian forum penyelesaian sengketa apabila terjadi pelanggaran hak dan kewajiban negara anggota. Dalam beberapa tulisan Syahmin AK dengan judul Aspek-aspek hukum perdagangan internasional dalam GATT dan WTO menjelaskan antara lain bahwa GATT sebagai forum negosiasi, GATT menyelesaikan serangkaian perundingan formal untuk meningkatkan perdagangan dunia melalui upaya mengurangi hambatanhambatan terhadap perdagangan internasional dunia, baik berupa tarif maupun non tarif.

- GATT sebagai organisaisi internasional, dengan kegiatan yang semakin luas. GATT yang semula hanya merupakan suatu perjanjian internasional, secara pragmatis telah menjadi suatu organisasi internasional secara defacto masyarakat internasional telah menerima GATT sebagai organisasi internasional.

Lebih lanjut menyatakan bahwa tahapan dalam penyelesaian sengketa dagang dalam perdagangan Internasional. Berikut ini adalah tahapan-tahapan dalam penyelesaian sengketa dagang di dalam WTO. Tujuan dari mekanisme penyelesaian sengketa dagang di WTO adalah untuk menguatkan solusi yang positif terhadap sengketa. Tahapan pertama adalah konsultasi antara pihakpihak yang bersengketa, setiap anggota harus menjawab secara tepat dalam waktu sepuluh hari untuk meminta diadakan konsultasi dan memasuki periode konsultasi selama tiga puluh hari setelah waktu permohonan. (Syahmin AK, 2004: 422-43).

Untuk memastikan kejelasannya, setiap permohonan untuk konsultasi harus diberitahukan secara tertulis, kemudian disebutkan dan alasan-alasan permohonan konsultasi termasuk dasar-dasar hukum untuk pengaduan. Bila konsultasi gagal dan kedua pihak setuju, masalah ini dapat diajukan ke Direktur Jenderal WTO yang akan siap menawarkan diadakan good offices, consultasi, atau mediasi dalam menyelesaikan sengketa.

Pengaturan penyelesaian sengketa dagang bagian negara-negara berkembang. Gambaran umum mengenai sistem penyelesaian sengketa dalam WTO. telah menjadi suatu alat yang dibutuhkan dalam menyelesaikan sengketa perdagangan internasional yang menjadi antara sesame anggota WTO. Semenjak timbulnya masalah mengenai 
pelaksanaan proses pelaksanaan keputusan atas sengketa yang terjadi berdasarkan pada sistem sebelumnya yaitu GATT. Penyelesaian sengketa dalam WTO telah berkembang menjadi prosedur adjudikasi dan dalam perkembangannya telah mewujudkan sistem penyelesaian sengketa berdasarkan atas suatu sistem structural yang baku, termasuk di dalamnya prosedur- prosedur formal yang harus dipenuhi dan pelaksanaan atas tiap keputusan yang diambil Sistem penyelesaian sengketa WTO berkembang, sebagai wujud untuk mengakomodir kepentingan nasional masing-masing negara anggota dalam rangka terwujudnya kepentingan masyarakat internasional. (HS. Kartodjoemena, 1996: 177)

Perkembangan terakhir dari sistem penyelesaian sengketa dalam GATT adalah diterimanya WTO sejak 1 Januari 1995 yang melahirkan sistem penyelesaian sengketa yang lebih komprehensif, legalitas, dan lebih memberikan perlindungan kepada negara berkembang. Penyelesaian sengketa dalam WTO lebih berpijak kepada ruleBsed dimana prinsip terakhir ini terlihat dalam sistem GATT. Sehingga dengan demikian, tiap negara dapat menerima dan merasa nyaman dengan keberadaan mereka dalam keanggotaan WTO itu sendiri.

Perjanjian GATT adalah suatu dokumen yuridis. Dalam dokumen ini tercantum baik hak maupun kewajiban negara peserta perjanjian. Adanya serangkaian hak dan kewajiban secara eksplisit dicantumkan tentunya sering menimbulkan sengketa. Sebagai lembaga, maka GATT telah menerapkan tata cara dan prosedur untuk menangani sengketa yang timbul antara negara peserta. dalam konteks hukum internasional secara umum, masyarakat internasional memberikan peluang untuk melakukan penyelesaian sengketa antara negaranegara melalui berbagai cara. Sengketa antar negara dapat diatasi melalui dimana pihak yang bersengketa menerima penyelesaian sengketa yang dirumuskan dan diputuskan oleh pihak ketiga

a. Kegagalan negara peserta lain untuk melakukan kewajibannyakewajibannya menurut perjanjian ini atau

b. Penerapan suatu tindakan oleh suatu negara-negara peserta lain apakah itu bertentangan atau tidak dengan ketentuan perjanjian ini atau

c. Adanya situasi-situasi lain.

Berikut ini adalah tahapan-tahapan dalam penyelesaian sengketa dagang melalui WTO/GATT:

a. Konsultasi. Pasal III dari WTO Agreement menyatakan salah satu fungsi utamanya adalah dari the understanding on Rule Procedures the settlement of Disputes. Suatu dokumen yang telah disetujui dalam Uruguay Round adalah dispute settlement understanding (DSU) yang merupakan the first fully integrated text of GATT dispute settlement procedures. Konsultasi merupakan upaya yang dilakukan oleh para pihak yang berselisih sebelum perkara 
Ukas: Analisis Yuridis Mekanisme Penyelesaian Sengketa Perdagangan Internasional...

tersebut diproses oleh majelis hakim (panels) di WTO/GATT. Jadi sebenarnya yang dimaksud tidak lebih dari sekedar suatu upaya penyelesaian sengketa secara musyawarah diantara para pihak untuk mencapai suatu solusi yang memuaskan kedua belah pihak (winwin solution). Tujuan dari mekanisme penyelesaian dagang di WTO adalah menguatkan solusi yang positif terhadap sengketa. Tahap pertama adalah konsultasi antara pihak-pihak yang bersengketa. Setiap anggota harus menjawab secara tepat dalam waktu sepuluh hari untuk meminta diadakan konsultasi dan memasuki periode konsultasi selama tiga puluh hari setelah waktu permohonan.

b. Pembentukan Panel. Dengan dibentuknya sistem panel maka apabila suatu sengketa tidak dapat diselesaikan melalui konsultasi dan konsilidasi bilateral, jalan keluar yang tersedia adalah didirikannya suatu panel. Sejak dibentuknya sistem panel, banyak masalah GATTT yang telah diselesaikan melalui panel, pada masa mendatang, dalam WTO, jumlah panel akan lebih banyak lagi dan masalah yang akan ditangani juga semakin lebih luas sehingga memerlukan jaringan panel yang lebih luas (Syahmin AK, 2004: 28)

c. Prosedur-prosedur panel. Ini menunjukkan bahwa periode dimana panel melaksanakan pengujian masalah, selanjutnya term of refrence dan komposisi panel disetujui. Kemudian panel memberikan laporan kepada para pihak yang sengketa tidak boleh lebih dari enam bulan. Dalam hal penting, termasuk untuk barang -barang yang mudah rusak, akan dapat dipercepat menjadi tiga bulan. Apabila tidak ada masalah, waktu pembentukan ke sirkulasi laporan kepada anggota tidak boleh lebih dari Sembilan bulan.

\section{Dampak Dari Ketentuan Penyelesaian Sengketa Perdagangan Melalui WTO Terhadap Kebijaksanaan \\ Pembangunan Hukum Nasional.}

Dengan adanya ketentuan-ketentuan penyelesaian sengketa melalui WTO hal sangat besar pengaruhnya terhadap pembangunan nasional. Di dalam ketentuan WTO tersebut ada beberapa prinsip utama, yaitu adanya non discrimination yang merupakan prinsip utama yang biasa disebut disebut sebagian prinsip "Most Favored Nations" (MFN). (Muhammad Sood, 2012: 57)

Berdasarkan prinsip ini, perlakuan suatu negara harus sama, tidak ada pengecualian, apabila perjanjian dua negara harus diberlakukan untuk semua negara. National Treatment, artinya suatu negara harus memberikan perlakuan yang sama terhadap produksi dalam negeri. Dari kedua prinsip utama tersebut jelas sangat berpengaruh untuk pembangunan hukum nasional, dimana pembentukannya harus sesuai dengan prinsip tersebut, prinsip tersebut tidak bertentangan dengan Dasar Negara, penyelesaian sengketa 
WTO bukan merupakan tekanan bagi negara-negara termasuk Indonesia terhadap peraturan nasionalny, bagi Indonesia kewajiban untuk menyesuaikan Peraturan perundang-undangan di segala bidang di perdagangan internasional benar harus sejalan dengan ketentuan perdagangan internasional (GATT-WTO), dan ketentuan seperti ini semakin dirasakan, karena negara mitra dagang Indonesia semakin banyak mengajukan tuntutan agar Indonesia memenuhi kewajibannya, sehubungan dengan hal tersebut beberapa peraturan telah berhasil disesuaikan dengan ketentuan WTO diantaranya adalah ketentuan di bidang HaKI yaitu Undang-Undang No. 12 tahun 1997 atas perubahan Undang-Undang No. 16 tahun 1982, Hak Cipta sebagaimana telah diubah dengan Undang-Undang No. 7 tahun 1987. Undang-Undang No. 13 tahun 1997 tentang perubahan atas Undang-Undang No. 6 tahun 1989 tentang Paten, dan Undang-Undang No. 14 tahun 1997 tentang perubahan Undang-Undang No. 19/1992 tentang Merek, dan beberapa ketentuan Peraturan perundang undangan lainnya seperti TRIMs, modal- investasi termasuk perusahaan, kesemuanya untuk kemajuan dan menyesuaikan serta peningkatan pembangunan hukum nasional dalam kerangka GATT- WTO.

Dalam hal lain beberapa ketentuan lainnya yang sudah diatur dalam rangka pembangunan Hukum Nasional suatru Negara, seperti pada bulan Desember 1996 di Singapura diadakan pertemuan para Menteri dari anggota WTO yaitu pertemuan otoritas tertinggi, sesuai keputusan para Menteri Perdagangan di Marakesh Marocco bulan April 1995 yakni saat kesepakatan Putaran Uruquay yang juga memutuskan pembentukan organisasi lainnya di bawah WTO, ditandatangani pertemuan Singapura ini pada dasarnya dimaksudkan untuk mengadakan peninjauan atau penilaian (review) terhadap implementasi dari hasilhasil Putaran Uruquay, pada 1 Januari 1995 dan juga membahas beberapa isu lainnya selama itu masih dalam ruang lingkup dan fungsi WTO, termasuk isuisu baru, sekaligus akan menyusun program kerja WTO untuk masa akan mendatang, yakni hingga pertemuan Menteri WTO berikutnya dilangsungkan. Banyak negara yang terlibat di WTO ini berimplikasi banyak bagi hal-hal termasuk dalam buletin agenda cakupannya termasuk meninjau implementasi kesepakatan Putaran Uruguay atau keputusan-keputusan WTO lainnya, melanjutkan negosiasi-negosiasi mengenai masalah-masalah yang belum bisa diselesaikan, selain itu dalam agenda berikutnya akan mulai dibahas pengkaitan perdagangan dengan isu lingkungan (trade and environment), isu-isu baru (new issues) termasuk issue liberalisasi perdagangan internasional.

Mekanisme/dan Prosedur Penyelesaian Sengketa WTO, meliputi:

\section{- Tahapan 1}

Konsultasi. Pertama-tama pihak yang bersengketa harus berupaya untuk menyelesaikan permasalahannya melalui konsultasi bilateral. Bila pihak yang 
Ukas: Analisis Yuridis Mekanisme Penyelesaian Sengketa Perdagangan Internasional...

bersengketa gagal mencapai kesepakatan dan menyetujui untuk membawanya ke Direktur Jenderal WTO yang dalam hal ini bertindak dalam kapasitas "ex officio.

- Tahap 2

Permintaan suatu panel. Bila mana setelah enam puluh hari konsultasi tersebut juga gagal dicapai keputusan, permohonan meminta DSB membentuk suatu panel untuk mengadakan pengkajian.

- Tahap 3

Pekerjaan Panel. Panel dalam melaksanakan tugasnya, akan melakukan/mengadakan hal-hal di antaranya mengadakan pertemuanpertemuan dengan pihak-pihak yang bersengketa,

mendapatkan/mengumpulkan masingmasing bantahan, pertemuan-pertemuan tambahan bila dianggap perlu, menyiapkan laporan tentang fakta dan menyampaikan laporan akhir.

- $\quad$ Tahap 4

Pengesahan Keputusan. Dalam enam puluh hari, laporan panel harus disahkan oleh BPS. Bila salah satu pihak bersengketa tidak setuju dengan suatu masalah tentang ketentuan atau legalitas interpretasi yang berkembang selama dalam proses, pihak yang berkeberatan tersebut dapat mengajukan keberatannya.

Dari tahapan-tahapan yang ada di atas dampaknya adalah memudahkan para pihak menyelesaikan sengketanya dengan cepat, utamanya masalah sengketa bisnis.

\section{SIMPULAN DAN SARAN}

\section{Simpulan}

a. Mekanisme penyelesaian sengketa dalam perjanjian kaitannya dengan perdagangan internasional pada intinya mengacu pada ketentuan pasal-pasal yang terkait dalam GATT 1947, yang intinya adalah pertama tahap konsultasi yang berupaya untuk menyelesaikan permasalahannya, kemudian tahap kedua yaitu permintaan suatu panel. Diharapkan dengan tahap-tahapan tersebut akan tercapai kesepakatan dalam penyelesaian sengketa perdagangan internasional.

b. Dampak yang ditimbulkan dari ketentuan Pasal 22-23 GATT (penyelesaian sengketa perdagangan internasional melalui WTO), adalah menciptakan kebersamaan dan menghilangkan rasa kebencian, menyelesaikan sengketa dengan cara musyawarah dan atau damai, agar kemajuan dan keharmonisan dalam ekspor-impor semakin tercipta dan dapat di tingkatkan.

\section{Saran}

a. WTO Sebagai salah satu organisasi perdagangan Internasional dalam menyelesaikan sengketa perdagangan internasional disarankan harus bersifat independentsi yaitu menempatkan seluruh anggotanya pada posisi yang sama.

b. Berbagai bentuk dan kalangan anggota GATT dan WTO menyarankan sebaiknya mendahulukan cara-cara yang 
persuasif, yakni cara-cara damai dalam penyelesaian sengketanya.

\section{DAFTAR PUSTAKA}

\section{Buku-Buku}

Muchtar Kusumaatmadja, 1987, Hukum Internasional, Binacipta, Bandung.

Boer Mauna, Hukum Internasional, Peranan dan Fungsi dalam Era Dinamaika Global, Alumni, Bandung,

David Harland, 2001, The Consumer in the blabalized information Society The information of information.

Huala Adolf, 2005, Hukum Perdagangan Internasional, Raja Grafindo Persada, Jakarta,

Syahmin AK, 2004, Hukum Perdagangan Internasional (Dalam Kerangka Studi Analisis, ) Naskah Tutorial FH UNSRIT, Palembang.

Syahmin AK, 2006, Hukum Dagang Internasional, Dalam Kerangka Studi Analisis, PT. Raja Grafindo Persada, Jakarta.
Lawrence le, 2007, Legal Aspect of WTO Dispute Settlement mechawtastem settlement, Equarble, World.

H.S. Salim, 2012, Perkembangan Teori Dalam Ilmu Hukum, PT. Raja Grafindo Persada, Jakarta.

\section{Peraturan Perundang-undangan}

Undang-Undang Nomor 7 Tahun 1994 Tentang Pengesahan Agreement Establishing The World Trade Organization.

Undang-Undang Nomor 30 Tahun 1999. Tentang Pengaturan Alternatif Penyelesaian Sengketa.

GATT, khususnya Paragraph 1 rticle XXIII

ICC, The International Chamber of commerce.

Undang-Undang Nomor 5 Tahun 1968 Tentang Persetujuan atas Konvensi Penyelesaian Perselisihan Antar Negara dan Warga Negara Asing. 